\title{
Relative Effects of Cooperative Learning Approach on Secondary School Students' Attitudes in Kiswahili Language Comprehension in Kisii Central Sub-County, Kenya
}

\author{
Henry Nyabiosi, Prof. Samuel W. Wachanga, Prof. Aswani Buliba
}

Egerton University, Kenya

\begin{abstract}
Kiswahili is the national and official language of Kenya and is a compulsory subject in the school curriculum at primary and secondary school levels. In the Kenya Certificate of Secondary Education (KCSE) examinations, the Kiswahili language paper constitutes tests on comprehension (passage), summary, grammar and sociolinguistics. The Kenya National Examination Council (KNEC) examination reports show a poor performance in comprehension by secondary school students. Perhaps the poor performance might be attributed to the inappropriate teaching approaches among other factors. The study was therefore designed to develop and explore the instructional potential of a Cooperative Learning (CL) approach in the teaching of Kiswahili Language Comprehension. This study was conducted in secondary schools in Kisii Central SubCounty, Kenya. The study adopted the Solomon Four Non-equivalent Control Group Design. It involved 160 Form Two students that were drawn from four schools. Simple random sampling technique was used to select the schools and classes that participated in the study. Students' Attitude Questionnaire (SAQ) was used to collect data. SAQ was checked for validity and piloted for reliability. The tool yielded reliability coefficient of 0.79. The collected data were analysed using both descriptive and inferential statistics. Descriptive statistics were used to describe and summarize raw data using mean, standard deviation, frequencies and percentages. The t-test, ANOVA and ANCOVA were employed for statistical tests of significance at alpha $(\alpha)=0.05$. The findings of the study showed that the Cooperative Learning Approach significantly improved the learners' attitudes towards learning of Kiswahili Language Comprehension. This study may help secondary school Kiswahili teachers as they seek to improve performance in the subject.
\end{abstract}

Keywords: Cooperative Learning, Attitudes, Secondary School Students, Kiswahili Language Comprehension.

\section{INTRODUCTION}

Kiswahili language owes its origins in the coastal regions of East Africa. The language spread inland through trade and development of the railway. Kiswahili is generally seen as a unifying language for East African region socially, politically, and commercially. It has grown in administrative and interethnic borders to claim being an all-African language (Kimemia, 2001). Kimemia (2001) says that Kiswahili is not only an Eastern and Central African language but it has permeated to the rest of African countries including Zaire, Rwanda and Burundi. In the rest of the world it is taught and used in countries such as USA, Britain, and France. According to Atieno (2001), Kiswahili is the most widely spoken African language with about 50 million speakers in East and Central Africa, particularly Kenya, Tanzania, Uganda and Congo. Warigi (2002) expresses a hope of Kiswahili being adopted as one of the working languages of African Union (AU).

Kiswahili has been enshrined in the Kenyan Constitution as one of the National and Official Languages in Kenya. The new Constitution, which was promulgated in the year 2010, in Chapter Two states:

(1)The national language of the Republic is Kiswahili.

(2)The official languages of the Republic are Kiswahili and English.

(3) The State shall-

(a) promote and protect the diversity of language of the people of Kenya; and

(b) promote the development and use of indigenous languages, Kenyan Sign language, Braille and other communication formats and technologies accessible to persons with disabilities, (Kenya Government, 2010) 
The development of Kiswahili in the education system has remoulded the western oriented educational model into a true Kenyan model. This has taken-off since the introduction of 8.4.4 system of education in 1985. Bogonko (1992) said that, if any education is to be effective it must be passed through language. So there should be a definite language policy in schools that will enable learners to acquire the language skills such as reading, writing and speaking for them to communicate in school and society.

The educational commissions in Kenya after independence like the Ominde and Mackay commissions emphasized the inclusion of the Kiswahili language in the education curriculum. It became compulsory and examinable in the Kenya Certificate of Primary Education (KCPE) in 1986 (Bogonko, 1992).

In examinations, Kiswahili language paper examines the candidates' knowledge and understanding of language conventions currently in use as well as the candidate's ability and capacity to handle and apply such conventions in their attempt to convey meaning. The test of comprehension is one of the sections that constitute the paper. According to the Kenya Institute of Education (KIE) Secondary School Kiswahili language syllabus, a student is expected, at the end of the secondary school course, to be able to understand a passage by following its content, arguments and narrative sequence and infer information, meanings, attitudes, intentions and present such information in a variety of ways (KIE, 1992).

However, students get difficulties in learning the subject as evidenced by poor performances reported in examination reports (KNEC, 2002). This shows lack of mastery of the language. Since the year 2011 to 2014, the Kiswahili language grammar examination paper that is scored out of 80 marks had been performed below average. Question one, on comprehension, had been quoted all along, among the questions that were having a declining trend. In 2014, for instance, the Chief Examiner for the Kiswahili grammar paper lamented that there was a grim shocking picture of performance in comprehension, (KNEC, 2015). The poor performance may be attributed to the students' inability to read and comprehend the subject matter. Children with reading problems often lack the ability to organise materials, to sequence their work on paper and understand fully what is required of them from printed matter (Robinson, 1993). The teaching of comprehension in Kiswahili language is expected to equip them with this ability. But the section containing comprehension in the Kiswahili Examination shown in Table 1 is performed below average since the year 2011- 2014 (KNEC, 2015). Announcing the KCSE results for the year 2013, the Minister for Education said that the six subjects that showed a drop in performance were Kiswahili, Home Science, Art \& Design, Aviation, Technology and Germany (Fortunate, 2014).

Table1. Kiswahili Examination Results for the Year 2011-2014

\begin{tabular}{|l|l|l|l|l|l|}
\hline Year & Paper & Candidates & Maximum score & Mean score & Deviation \\
\hline $\mathbf{2 0 1 1}$ & 1 & & 40 & 16.43 & 5.61 \\
& 2 & & 80 & 43.45 & 13.18 \\
& 3 & & 80 & 37.76 & 14.96 \\
& Total & 410,807 & $\mathbf{2 0 0}$ & 97.63 & 29.81 \\
& & & $\mathbf{\%}$ & $\mathbf{4 8 . 8 2 \%}$ & \\
\hline $\mathbf{2 0 1 2}$ & 1 & & 40 & 10.43 & 3.63 \\
& 2 & & 80 & 29.06 & 10.77 \\
& 3 & & 80 & 32.14 & 15.15 \\
& & & $\mathbf{2 0 0}$ & 71.62 & 25.71 \\
& Total & 433,886 & $\mathbf{\%}$ & $\mathbf{3 5 . 8 2} \%$ & \\
\hline $\mathbf{2 0 1 3}$ & 1 & & 40 & 18.46 & 5.44 \\
& 2 & & 80 & 29.92 & 12.68 \\
& 3 & 445,555 & 80 & 34.82 & 14.92 \\
& & $\mathbf{2 0 0}$ & 83.19 & 29.77 \\
\hline $\mathbf{2 0 1 4}$ & Total & & $\mathbf{\%}$ & $\mathbf{4 1 . 6 0 \%}$ & \\
& 2 & & 40 & 20.17 & 5.26 \\
& 3 & & 80 & 32.27 & 12.60 \\
& & & 80 & 42.93 & 15.81 \\
& Total & 482122 & $\mathbf{2 0 0}$ & 95.36 & 29.88 \\
\hline
\end{tabular}

Source: Kenya National Examinations (KNEC) Report, 2015 P.5 
The scores for Paper 2 dropped from 43.45 in the year 2011 to 29.06 in 2012. The score is almost the same in the year 2013 which had an average of 29.92; there is a very slight improvement but still far below average. In the year 2014 it improved minimally to 32.27. The items on comprehension and summary gave the candidates difficulties. Most of the candidates lost their scores in Comprehension, Summary and Sociolinguistics (KNEC, 2015).

Table 1 shows that the overall percentage performance in Kiswahili language is below average; in the year $2011,48.82 \%$, in $2012,35.82 \%$, in $2013,41.60 \%$ and $47.7 \%$ in 2014 . However, it has made a significant improvement in 2014 but still has not managed to be above average.

In an increasingly competitive society, the minimum requirements into various courses in higher institutions of learning have gone up therefore attaining higher grades at KCSE is, of utmost importance. Students in Kisii Central Sub-county which was the focus of this study has been performing dismally in Kiswahili language. Examination analysis of the Sub-County from Kisii Central Sub-County Quality Assurance Standards' office confirms this worrying trend of poor performance. Table 2 shows the performance in Kiswahili in the Sub-County in four years consecutively.

Table2. Students' Performance in Kiswahili at KCSE in Term of \% Mean Score from the Year 2011-2014 in Kisi Central Sub County

\begin{tabular}{|l|l|l|l|l|}
\hline YEAR & $\mathbf{2 0 1 1}$ & $\mathbf{2 0 1 2}$ & $\mathbf{2 0 1 3}$ & $\mathbf{2 0 1 4}$ \\
\hline Mean Score \% & 43.58 & 39.91 & 40.09 & 43.91 \\
\hline DV & 4.22 & 0.030 & 2.08 & 2.20 \\
\hline
\end{tabular}

Source: Kisii Central Sub-County QASO Office 2015

From Table 2, it is evident that there is a serious problem in the performance in Kiswahili. The appalling scenario is due to a host of factors including students' attitudes towards Kiswahili teaching and the conventional teaching approaches used by teachers. Kimemia (2001) says that the approach of teaching Kiswahili requires further re-examination and re-definition. The "talk and chalk" approach and the rote-learning approach, which are currently widespread in Kenyan schools, are out of date and educationally inappropriate. All language aspects of skills should be developed in the learning and teaching situation. These aspects include, listening, talking, questioning, answering, reading and writing. The development of language skills will enable the pupils to acquire competence and confidence in language and will greatly enhance their understanding and retention. According to Robinson (1993), there should be better provision of materials for less able readers. Inadequate supply of materials renders students not able to have reading and learning experiences.

According to Oduor (2003), students have a negative attitude towards Kiswahili as a subject thus they perform poorly in the subject in National examinations. Arends (1994), asserts that the students' attitudes are vital on the quality of academic work. Ajizan (1988) views attitude as a disposition to respond favourably to an object, person, institution or event. Baker (1992) looks at attitude as a hypothetical construct used to explain the direction and persistence of human behaviour. Finally, Good (1975) says that attitude is a predisposition or tendency to react specifically towards an object, situation or value, usually accompanied by feelings and emotions. It's worth noting that attitude cannot be directly observed but must be inferred from overt behaviour, both verbal and non-verbal.

Language leaning therefore is affected by the attitude of learners towards the subject. Motivated and de-motivated students have different perceptions of the curriculum. The perceptions are responsible for their attitudes. Meenakshi (2008) argues that an individual's perception of the class teacher, peer group, syllabus and his/her awareness of future needs affect his or her attitude to language learning.

Akey (2006) carried a longitudinal study among high school students of grade 9-11 to ascertain if there exists any relation between school context, student attitudes and academic achievement. In the study, he found that perceived academic competence (attitude) had a positive influence on reading achievement among high school students. Those students who had a positive attitude towards reading had a higher achievement than those who had negative attitude.

Attitude has recently received considerable attention from both the first and second language researchers. Learning occurs more easily, when the learner has a positive attitude towards the language and learning, (Starks \& Paltridge, 1996). Chamber (1999) state that student's attitude is an 
integral part of learning and that it should therefore become an essential component in second language pedagogy. Haitema (2014) from his study on attitude reveals that there is a positive relationship between affective characteristics and language achievement. Weinburg (1998) in his study argues that there are several reasons research on students' attitudes towards language learning is important. First, attitudes towards learning are believed to influence behaviours such as selecting and reading books, speaking in that language among others. Second, a relationship between attitudes and achievement has been shown to exist. The study reported that there is support for the preposition that attitudes influence achievement, rather than achievement influencing attitudes. It can be argued that attitudes influence one's behaviours' inner mood and therefore, learning. Thus, it is clear that there is interaction between language learning and the environmental components in which the student grew up. Both negative and positive attitudes have a strong impact on the success of language learning.

The aim of teaching comprehension in Kenyan secondary schools, is to enable students to understand texts by making meaning of the words and phrases then presenting the information in many ways in life. Nevertheless, it seems the goal is not being achieved (KIE, 1992). The hindrances may be the teaching approaches, negative attitudes (Robinson, 1993), inadequate instructional resources (Hall, 1992) or inability of the students to read and comprehend. However, a specific approach had not been stipulated which could rectify the situation. Thus by employing the Cooperative Learning Approach, the researchers in this study hoped to improve the situation.

Cooperative Learning is a teaching and learning approach that requires active involvement of students through small-group interaction (Robinson, 1993). Students tutor one another on the task given. The duty of the teacher is to guide and coach them on how to form the groups and how to study. In the event of tutoring themselves, the low-achieving students can benefit from the high-achieving students. The high-achievers tutor low-achievers and in the process the high-achievers gain academically because serving as a tutor requires thinking more deeply about the relationships and meanings of the subject under study. So everybody benefits (Arends, 1994).

Arends (1994), reviewed the studies that had been done between the years 1972 and 1986, investigating the effects of cooperative learning on achievement. The studies were done in United States, Israel, Nigeria and Germany on spelling, reading and writing, geography and mathematics. Out of the 45 studies, 37 of them showed that cooperative learning classes significantly out-performed control group classes in academic achievement. Eight studies found no differences. None of the studies showed negative effects of cooperative learning. Thus, the researchers hoped that by employing Cooperative Learning (CL) in the teaching of Kiswahili language comprehension, the students' attitudes towards the subject may be improved.

\section{Statement of the Problem}

Students experience difficulties in attempting the section on comprehension in the Kenya Certificate of Secondary Education (KCSE) Kiswahili language examinations. The section is performed below average as evidenced in the KNEC reports (KNEC, 2015). One of the reasons for this achievement may be the attitudes held by students in learning comprehension. These attitudes may be caused by the method of teaching. The CL approach may help address this problem but its use in addressing students attitudes in learning of Kiswahili has not been determined in Kenya. Consequently, the researchers found it useful to develop a Cooperative Learning (CL) approach and establish its effect on students' attitudes towards the subject.

\section{OBJECTIVE OF THE STUDY}

The following objective guided the study:

To determine whether there is any significant difference in students' attitudes towards the learning of Kiswahili Language Comprehension between those exposed to CL approach and those exposed to Conventional Teaching Approaches.

\subsection{Hypothesis of the Study}

The following null hypothesis was statistically tested:

Ho1: There is no statistically significant difference in students' attitudes towards the learning of Kiswahili language comprehension between those exposed to CL approach and those exposed to conventional teaching approaches. 
Relative Effects of Cooperative Learning Approach on Secondary School Students' Attitudes in Kiswahili Language Comprehension in Kisii Central Sub-County, Kenya

\subsection{Conceptual Framework}

Figure 1 shows the Conceptual Framework for determining the effect of using CL approach on students' attitudes towards Kiswahili language comprehension.

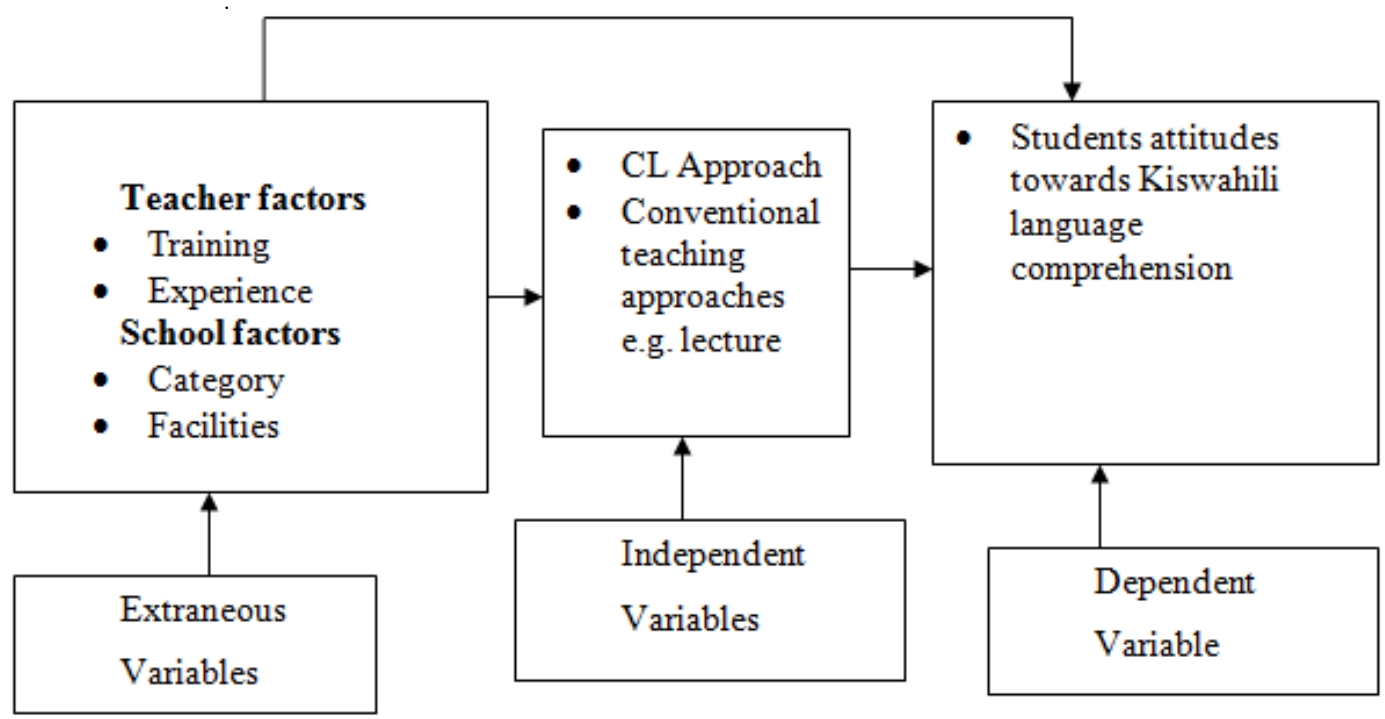

Figure1. Conceptual Framework showing relationship among the variables

School category and facilities plus the teachers' training and experience in the school determined the approaches teachers used in teaching Kiswahili comprehension. The approaches used then influenced the student's attitudes towards the subject. To control for the extraneous variables the researchers involved trained teachers with similar experience. They also used Sub-County category of schools with almost similar characteristics in terms of facilities and learners' abilities. Also by the use of ANCOVA for data analysis, the researchers were able to take care of any initial differences among the groups.

\subsection{Research Design}

The study adopted the Solomon Four Non-equivalent Control Group Research Design. The design was considered appropriate because the classes which were involved were intact and could not be reconstituted for research purposes (Borg \& Gall, 1989). The design also provides adequate control of variables that may contaminate the study. It involves a random assignment of intact classes of subjects to four groups, two groups being experimental and the other two as control groups. Figure 2 shows the assignment of classes.

\begin{tabular}{|c|c|c|c|c|}
\hline Group & Pre-test & Treatment & Post-test & \\
\hline$\overline{\mathrm{I}}$ & $\mathrm{O}_{1}$ & $\mathrm{X}$ & $\mathrm{O}_{2}$ & (Experimental Group) \\
\hline II & $\mathrm{O}_{3}$ & - & $\mathrm{O}_{4}$ & (Control Group) \\
\hline III & - & $\mathrm{X}$ & $\mathrm{O}_{5}$ & (Experimental Group) \\
\hline IV & - & - & $\mathrm{O}_{6}$ & (Control Group) \\
\hline
\end{tabular}

Figure2. Solomon Four - Non-equivalent Control Group Design

Where: $\mathrm{O}_{1}$ and $\mathrm{O}_{3}$ are pre-tests

$$
\begin{aligned}
& \mathrm{O}_{2}, \mathrm{O}_{4}, \mathrm{O}_{5} \text { and } \mathrm{O}_{6} \text { post-tests } \\
& \mathrm{X} \text { is the treatment } \\
& \text {--- Groups are intact } \\
& \text { _ control condition }
\end{aligned}
$$


The design has four groups of subjects; Group I and III are the Experimental Groups while Groups II and IV form the Control Group. Only Groups I and II were subjected to pre-tests $\left(\mathrm{O}_{1}\right.$ and $\left.\mathrm{O}_{3}\right)$, but at the end of the course all the four groups sat for the post-tests.

\subsection{Sampling Procedure and Sample Size}

The researchers used the list of Sub-County secondary schools in the QASO's office as the sampling frame. Using this list, the researchers employed simple random sampling technique to select four schools that were involved in the study. One Form Two class was chosen from each of the participating schools. In situations where a school had more than one stream, simple random sampling was applied to select a class. Coolican (1994) recommended at least 40 subjects per treatment class. The sample sizes of the four groups I, II, III and IV which took part in the study is summarized in Table 3.

Table3. Sample of the Students by Group

\begin{tabular}{|l|l|}
\hline Group & N \\
\hline Group I & 40 \\
\hline Group II & 42 \\
\hline Group III & 43 \\
\hline Group IV & 42 \\
\hline
\end{tabular}

\subsection{Instrumentation}

Students' Attitude Questionnaire (SAQ) was used to collect data. The SAQ had 20 structured closeended items that solicited student's feelings towards the Kiswahili language comprehension learning lessons. It employed a Five Point Likert scale to measure the attitudes. The responses to items in the questionnaire had 1 point (lowest) for strongly disagree and 5 points (highest) for strongly agree. The SAQ was checked for content and face validity by a team of 5 experts from the Department of Curriculum, Instruction and Educational Management. Content validity ensured that the subject area was adequately covered, (Borg \& Gall, 1989). Then SAQ was piloted for reliability using a class from a school in the Sub-County which did not take part in the actual study. The reliability of the instrument was estimated using the Cronbach alpha method.

The method is recommended when the instrument is administered once and the items in it are the closed-ended Likert type ((Borg \& Gall, 1989). SAQ yielded reliability coefficient of 0.79. This coefficient is well above the recommended 0.7 threshold (Fraenkel \& Wallen, 2000; Mugenda \& Mugenda 1999). The instrument was thus considered reliable.

\section{Data Collection}

The researchers got an introductory letter from Egerton University and then sought a research permit from the National Council of Science and Technology. Once the permit was granted those who participated in the study were formally contacted through their respective school heads. The Kiswahili teachers from experimental group schools were given a week's orientation course on the CL approach. Student Attitude Questionnaire was administered to students in Group I and II at the beginning of the course for purposes of ascertaining their entry level and homogeneity. All the four groups were then exposed to a series of 16 lessons in comprehension. Groups I and III were taught using the CL approach, while Group II and IV were taught using conventional approaches. At the end of the course all the four groups sat for SAQ post-tests. The pre-test and post-test data were collected and organised for analysis.

\subsection{Data Analysis}

The raw data were checked for errors and corrections made where necessary. They were then coded and analysed with the aid of the Statistical Package for Social Sciences (SPSS). Data were described and summarized using frequencies, percentages, means and standard deviation. The hypothesis was tested at 0.05 level using the ANOVA and ANCOVA. A summary of the data analysis procedures are given in Table 4. 
Relative Effects of Cooperative Learning Approach on Secondary School Students' Attitudes in Kiswahili Language Comprehension in Kisii Central Sub-County, Kenya

Table4. Summary of Data Analysis procedure

\begin{tabular}{|c|c|c|c|}
\hline Hypothesis & $\begin{array}{l}\text { Independent } \\
\text { Variables }\end{array}$ & $\begin{array}{l}\text { Dependent } \\
\text { Variable }\end{array}$ & Statistical Test \\
\hline $\begin{array}{l}\text { There is no statistically significant } \\
\text { difference in students' attitudes towards } \\
\text { Kiswahili Language Comprehension } \\
\text { between those exposed to CL approach } \\
\text { and those exposed to conventional } \\
\text { teaching approach. }\end{array}$ & $\begin{array}{l}\text { Learning approach } \\
\text { - } \quad \text { CL approach } \\
\text { - } \quad \text { Conventional } \\
\quad \text { teaching } \\
\quad \text { approaches }\end{array}$ & $\begin{array}{l}\text { SAQ } \\
\text { Mean scores }\end{array}$ & $\begin{array}{l}\text { ANOVA and } \\
\text { ANCOVA }\end{array}$ \\
\hline
\end{tabular}

\section{RESUlTS AND DISCUSSION}

\subsection{Entry Behavior of Respondents}

The students in Groups I and II were pre-tested on SAQ before being exposed to the topic on Kiswahili Language Comprehension. The two groups were the only ones that were exposed to the pre-test and therefore provided a means of determining the respondents' entry behavior. Coolican (1994) avers that pre-testing helps a study to identify subjects' characteristics before the programme commences. The maximum pre-test scores of the dependent measurable SAQ 100 marks. The t-test was used to compare the pre-test mean scores of the two groups.

Table5. Comparison of Students' Pre-test Mean Scores on SAQ between Group I and II

\begin{tabular}{|l|l|l|l|l|l|l|l|}
\hline Scale & Group & N & Mean & SD & df & t-value & p-value \\
\hline SAQ & Group I & 40 & 54.80 & 6.00 & 80 & 1.11 & 0.27 \\
\hline & Group II & 42 & 56.58 & 6.88 & & & \\
\hline
\end{tabular}

The results revealed that the difference between the SAQ mean scores of the students in Group I $(\mathrm{M}=$ $54.80, \mathrm{SD}=6.00)$ was not statistically different from that $(\mathrm{M}=56.58, \mathrm{SD}=6.88)$ of their counterparts in Group II, $t(80)=1.11, p=0.27$. This implies that in terms of attitude the two Groups I and II were similar at the point of entry with respect to SAQ. The groups were considered suitable for the study as they were drawn from a stable population with comparable characteristics with respect to SAQ. The results showed that before the start of the experiment the groups I and II were homogenous in terms of attitude, thus, after the administration of the experiment any change in the results would be attributed to the treatment or lack of treatment given.

\subsection{Effect of CL Approach on Students Attitudes towards Kiswahili Language Comprehension}

The effect of CL on students' attitudes towards Kiswahili language comprehension was established by comparing the SAQ post-test mean scores and the gain of all the groups I, II, III and IV that participated in the study. The post-test comparisons involved all the four groups whereas the gain analysis involved groups I and II that were exposed to both the pre-test and post-test.

\subsection{Comparison of Students' Post-test Mean Scores on SAQ by Learning approach}

The post-test means and standard deviations of the four groups are in Table 6

Table6. SAQ Post-test Mean Scores and Standard Deviations by Group

\begin{tabular}{|l|l|l|l|}
\hline Group & N & Mean Max = 100 & Standard Deviation \\
\hline Group I & 40 & 68.00 & 2.07 \\
\hline Group II & 42 & 61.88 & 2.02 \\
\hline Group III & 43 & 69.45 & 6.83 \\
\hline Group IV & 42 & 60.99 & 3.46 \\
\hline
\end{tabular}

The results in Table 6 showed that the mean scores of the experimental groups $\mathrm{I}(\mathrm{M}=68.00, \mathrm{SD}=$ $2.07)$ and III $(69.45, \mathrm{SD}=6.83)$ were higher than those of the control groups II $(\mathrm{M}=61.88, \mathrm{SD}=$ 2.02) and IV $(\mathrm{M}=60.99, \mathrm{SD}=3.46)$. The results in the table shows that the attitudes towards Kiswahili Language comprehension of students exposed to CL was more positive than that of students taught using the conventional approach. The test of differences was done using ANOVA to establish whether the mean scores of the groups were significantly different at the 0.05 alpha level. 
Henry Nyabiosi et al.

Table7. One-way ANOVA Post-test SAQ Scores between Group I, II, III and IV

\begin{tabular}{|l|l|l|l|l|l|}
\hline Scale & Sum of Squares & Df & Mean Square & F-ratio & p-value \\
\hline Between groups & 2292.25 & 3 & 764.08 & 44.73 & $\mathbf{0 . 0 0 0}$ \\
\hline Within groups & 2784.01 & 163 & 17.080 & & \\
\hline Total & $\mathbf{5 0 7 6 . 2 6 .}$ & $\mathbf{1 6 6}$ & & & \\
\hline
\end{tabular}

* Significant at 0.05 level

The results of the analysis of variance of SAQ post-test in Table 7 revealed that the differences among the mean scores of the four groups was significant at the 0.05 level in favour the experimental groups I and III, $F(3,163)=44.74, p<0.05$. This implies that the students exposed to CL had a more positive attitude towards Kiswahili Language comprehension than their counterparts who were taught using conventional teaching approach as measured by SAQ. Further tests were done using the LSD Post Hoc test to reveal where pairwise differences were.

Table8. ANOVA LSD Post Hoc on SAQ Post-test Mean Scores

\begin{tabular}{|l|l|l|}
\hline Paired Group & Mean Difference & p-value \\
\hline Group I vs Group II & 6.12 & $0.000^{*}$ \\
\hline Group I vs Group III & -1.45 & 0.113 \\
\hline Group I vs Group IV & 7.01 & $0.000^{*}$ \\
\hline Group II vs Group III & -7.57 & $0.000^{*}$ \\
\hline Group II vs Group IV & 0.89 & 0.327 \\
\hline Group III vs Group IV & 8.45 & $0.000^{*}$ \\
\hline
\end{tabular}

The Post Hoc results in Table 8 revealed that there were significant differences between the following paired groups; I and II ( $\mathrm{p}<0.05)$, I and IV ( $p<0.05)$, II and III $(\mathrm{p}<0.05)$, and III and IV $(\mathrm{p}<0.05)$. The difference between the mean score of experimental groups pair I and III $(\mathrm{p}=0.113)$ and control groups pair II and IV ( $\mathrm{p}=0.327$ ) were not significantly different. The results showed that the students in the experimental groups I and III had more positive attitudes towards Kiswahili Language comprehension than those in groups II and IV which were taught using the convectional teaching approach.

Further tests were done using ANCOVA as it has features that levels out the initial differences among groups. The adjusted post-test SAQ mean scores for the four groups with Kenya Certificate of Primary Education (KCPE) grades as the covariate are summarized in Table 9.

Table9. Adjusted Students, SAQ Post-test Mean Scores Using KCPE Grades as the Covariate

\begin{tabular}{|l|l|l|}
\hline Group & N & Mean \\
\hline Group I & 40 & 68.36 \\
\hline Group II & 42 & 61.65 \\
\hline Group III & 43 & 69.26 \\
\hline Group IV & 42 & 61.08 \\
\hline
\end{tabular}

Data in Table 9 showed that the adjusted mean scores of the experimental groups $\mathrm{I}(\mathrm{M}=68.36)$ and III $(M=69.26)$ were higher than those of the control groups II $(M=61.65)$ and IV $(M=61.08)$ that were taught using conventional teaching approach. The ANCOVA was used to establish whether the mean scores of these groups were significantly different at the 0.05 level.

Table10. Analysis of Covariance (ANCOVA) of the Post-test Scores on SAQ with KCPE as Covariate

\begin{tabular}{|l|l|l|l|l|l|}
\hline Source & Sum of squares & df & Mean square & F- ratio & p-value \\
\hline Contrast & 2288.146 & 3 & 762.715 & 44.671 & $.000^{*}$ \\
\hline Error & 2731.860 & 163 & 17.074 & & \\
\hline
\end{tabular}

* Significant at 0.05

The results of the ANCOVA test in Table 10 showed that the difference in the adjusted SAQ mean scores among the groups were statistically significant in favour of the experimental groups, $\mathrm{F}(3,163)$ $=44.671, \mathrm{p}<0.05$. This implies that the attitudes towards Kiswahili Language comprehension of students in the experimental groups were more positive than those taught using the conventional teaching approach. In order to reveal where the differences were further tests were done using the ANCOVA Post Hoc. The pairwise multiple comparison results are summarized in Table 11. 
Relative Effects of Cooperative Learning Approach on Secondary School Students' Attitudes in Kiswahili Language Comprehension in Kisii Central Sub-County, Kenya

Table11. ANCOVA Pairwise Comparison of SAQ Post-test by Learning Approach

\begin{tabular}{|l|l|l|}
\hline Paired Group & Mean Difference & p-value \\
\hline Group I vs Group II & 6.71 & $0.000^{*}$ \\
\hline Group I vs Group III & 0.90 & 0.353 \\
\hline Group I vs Group IV & 7.28 & $0.000^{*}$ \\
\hline Group II vs Group III & -7.61 & $0.000^{*}$ \\
\hline Group II vs Group IV & 0.57 & 0.540 \\
\hline Group III vs Group IV & 8.18 & $0.000^{*}$ \\
\hline
\end{tabular}

Significant at 0.05

The results in Table 11 revealed there were significant differences between SAQ post-test mean scores of the pairs made up of Groups I and II ( $p<0.05)$, I and IV (0.000), II and III ( $<<0.05)$, and III and IV (0.000) at $\alpha=0.05$. However, the differences in the mean scores of Groups I and III ( $\mathrm{p}=$ 0.353 ) and II and IV (0.540) were not significant at the 0.05 level. These results showed that the experimental groups I and III were similar in terms of their attitudes as measured by the SAQ. The results further revealed that the control groups II and IV were comparable in terms of their attitudes towards Kiswahili language comprehension.

The results of both the ANOVA and ANCOVA tests showed that the difference in the SAQ mean scores among the four groups I, II, III and IV were statistically different in favour of the experimental groups. Therefore, $\mathrm{H}_{0} 1$ is rejected.

\subsection{Comparison of Students Mean Gain on SAQ by Learning Approach}

The SAQ pre-test analysis revealed that the students in the experimental group I was comparable to their counterparts in the control group II. In order to find out the improvement on the students attitudes towards Kiswahili Language comprehension after the course, the mean gain analysis was conducted. The mean gain which is the difference between the pre-test and post-test mean scores gives an indication of the relative effects of treatment on a group. The gains of groups I and II on SAQ are given in Table 12.

Table12. Students' SAQ Pre-test and Post-test Mean Scores, Standard Deviation and Gain by Learning Approach

\begin{tabular}{|l|l|l|}
\hline Scale & Group I N = 40 & Group II N = 42 \\
\hline Pre-test & 54.80 & 56.58 \\
\hline SD & 6.01 & 6.87 \\
\hline Post-test & 68.00 & 61.88 \\
\hline SD & 2.07 & 2.02 \\
\hline Mean Gain & $\mathbf{1 3 . 2 0}$ & $\mathbf{5 . 3 0}$ \\
\hline
\end{tabular}

Data in Table 12 showed that the mean scores of experimental group I $(\mathrm{M}=54.80, \mathrm{SD}=6.01)$ and control group II $(\mathrm{M}=56.58, \mathrm{SD}=6.87)$ were comparable at the point of entry. After being taught Kiswahili language comprehension using the CL (for Group I) and conventional approach (for Group II), the mean score of group I ( $M=68.00, \mathrm{SD}=2.07)$ was higher than that of group II $(\mathrm{M}=61.88, \mathrm{SD}$ $=2.02$ ). This shows that there was a remarkable improvement in the attitudes of the students in group I towards Kiswahili language comprehension as indicated by its gain. The experimental group I had a higher mean gain $(M=13.20)$ than that of the control group II $(M=5.30)$. The t-test was done to establish whether the difference between the gains of groups I and II was statistically significant at 0.05 level.

Table13. Comparison of SAQ Mean Gains of Group I and II

\begin{tabular}{|l|l|l|l|l|l|}
\hline Group & N & Mean Gain & df & t-value & p-value \\
\hline Group I & 40 & 13.20 & 80 & 6.85 & $0.000^{*}$ \\
\hline Group II & 42 & 5.30 & & & \\
\hline
\end{tabular}

Significant at 0.05 level

The results in Table 13 revealed that the difference between the mean gain of group I $(M=13.20)$ and group II $(M=5.30)$ was statistically significant at the 0.05 level in favour of Group I, $\mathrm{t}(80)=6.85, \mathrm{p}<$ 0.05 . Since the two groups were similar before the commencement of the course, the remarkable improvement in attitude of Group I was attributed to the CL. 


\subsection{Discussion of Results}

\subsubsection{The Effect of CLA on the Students' Attitudes towards the Learning of Kiswahili Language Comprehension}

The results of this study showed that CL had a positive effect on students' attitudes towards Kiswahili Language comprehension. The results are in line with those of Zakaria, Chin and Daud (2010). Their study carried out on two form one classes in Miri, Sarawak found out that cooperative learning approach improves students' attitude towards mathematics. The findings are similar to those of Gillies (2004) and Walmsley (2003). Their studies found an increase in students' attitudes after working in cooperative learning groups. The findings of this study are also in agreement with those of Van-Wyk (2010) which indicated that cooperative learning approach promoted positive students attitudes towards Economic Education.

The enhanced students' attitudes can be attributed to the ability of the cooperative approach to teach students how to work as a team and increases good relationships among them. Furthermore, it provides students with a pleasant classroom environment and helps them to explain difficult things to their colleagues thus enhancing their attitudes towards the subject under study (Zakaria et al, 2010). However, the approach requires a lot of teaching-learning materials, involves a lot of activities and requires a lot of time and thus is expensive to implement (Kose, Sahin, Ergun \& Gezer, 2010). It may also not be ideal for high achievers who are in the same group with fellow students who are low achievers. More often than not such students hate these arrangements as they have to wait for the low achievers who have no ideas on what is being done or have poor discussion skills (Bancroft, 2010). Despite these shortcomings, cooperative learning can be an effective way to deal with the attitudinal problems faced by students. It creates a comfortable non-stressful environment for learning and helps students to learn more, have more fun, and develop other skills such as learning how to work with one another (Scot, 2009). The attitudes of the learners improved because the weak and average pupils had their morale boosted by being grouped with clever children. In mixed social grouping children get encouraged to participate actively when they are beside their friends, or someone they like. Sometimes social grouping can help shy, timid pupils to come out.

\section{Conclusion}

Based on the findings of this study the following conclusion was made. Students who are taught Kiswahili Language Comprehension through Cooperative Learning Approach acquire higher positive attitudes towards the subject than those who are taught through Conventional Approach. Therefore, secondary school teachers should use this method in teaching Kiswahili.

\section{RECOMMENDATIONS}

The results of the study revealed that cooperative learning approach added value to the teaching of Kiswahili Language Comprehension resulting in higher students' positive attitudes and achievement. On the strength of the findings and conclusions, the following recommendations were made.

a) Teachers should be equipped with CL skills through in-service training at Sub-County, County and national levels.

b) Teachers should adopt the cooperative learning approach so as to provide students with the opportunity to enjoy the benefits associated with the approach.

c) The benefits of small group cooperative learning such as interacting with peers and accepting the views of others should be used to enhance the development of students' social abilities.

\section{REFERENCES}

Ajizan, I. (1988). Attitudes, personality and behaviour. Chiengo: Dorsey Press.

Akey, T.M. (2006).School context, student attitudes and behavior, and academic Achievement: An ex laboratory analysis. Retrievable@ http://www.org./publications/419/ Ful.pdf.

Arends I. R. (1994) Learning to teach. (Third Edition). Toronto: Mc Graw-Hill, Inc.

Atieno, R. (2001 October $14^{\text {th }}$ ). New Website to promote Kiswahili. Daily Nation, Nairobi: Nation Media Centre.

Baker, C. (1992). Attitude and language. Clevedon: Multilingual Matters.

Bancroft, B. L.(2010). Enhancing student achievement through cooperative learning at the elementary level. Unpublished MA Thesis. Northern Michigan University. 
Bogonko S, N, (1992). Reflections on education in East Africa. Nairobi: Oxford University Press.

Borg, W.R.\&Gall, M.D.(1989). Educational Research: An Introduction. New York, NY: Houghton Mifflin Company

Chamber, G.N. (1999). Motivating language learners. Cleve don: Multilingual matters Ltd. Company

Coolican, H (1994). Research approaches in psychology. London: Hodder and Stoughton Educational.

Fortunate, E. (2014, February: 28th). The 2006 KCSE Results Finally Out. Daily Nation. Nairobi: Nation Media Group.

Fraenkel, J.R. \& Wallen, N.N., (2000). How to design and evaluate research in education. New York, NY: Mc Graw -Hill Inc

Gardner, R. (1980). On the validity of effective variables in second language learning acquisition: conceptual and statistical considerations. Language learning, 30(2), 255-270.

Gillies, R. M. (2004). The effects of cooperative learning on junior high school students. Toronto: McGraw Hill Inc

Good, C. (1975). Dictionary of education. (3rd Ed). New York: M C Graw Hill Book

Haitema,, T.B., (2014). Student attitudes vis Avis foreign language in elementary schools (EFLS) : A longitudinal study. Chapel Hall: University of North Carolina.

Hall, C. (1992). Diagnosis and management of learning disabilities. London: Singular Publishing Group. Inc.

K.I.E. (1992). Secondary education syllabus (volume five). Nairobi: Kenya Literature Bureau.

K.N.E.C (2002) Examination report. Nairobi: Kenya National Examinations Council.

K.N.E.C. (2015). Examination report. Nairobi: Kenya National Examinations Council.

Kenya Government (2010). Kenya Constitution. Nairobi, Government Printer.

Kimemia, N. (2001). Kiswahili, the dilemma of developing the national language. Njoro; Egerton University Press.

Kose, S., Sahin, A., Ergun, A. \& Gezer, K. (2010). The effects of cooperative learning experience on eighth grade students' achievement and attitude toward science. ERIC Education, 3(1), 169-180.

Meenakshi, H. V. (2008). Learner's attitude and its impact on language learning. Uttar Pradesh: I. I. E. \& T.

Mugenda, O. M. \& Mugenda, A. G. (1999). Research methods. Quantitative and Qualitative approaches. Nairobi: Acts Press.

Odour, A. (2003 July 8) Kiswahili teacher shortage decried. Daily Standard. Nairobi; Standard Newspapers.

Robinson, O. (1993). Tackling learning difficulties; a whole school approach. Kent, Great Britain, Athenaeum Press Ltd.

Scot, J. (2009). Improving achievement and attitude through cooperative learning in math class. Action Research Projects, Paper 64

Starks, D., \& Paltridge, B. (1996) A note on using sociolinguistic method to study. London: Stanley thornes Ltd

Van-Wyk, M. M. (2010). The effects of the STAD-Cooperative learning method on student achievement, attitude and motivation in economics education. Journal of Social science, 33(2): 261-270 (2012).

Walmsley, A. L. (2003). Cooperative learning and its effects in a high school geometry. New York, Mc Graw Ltd

Warigi, G. $\left(2002\right.$, July, $\left.21^{\text {st }}\right)$. Kiswahili place on continental stage. Sunday Nation. Nairobi: Nation Media Centre.

Weinburgh, M.H. (1998). Gender, ethnicity, and grade level as prediction of middle school students' attitudes towards science. New York McGraw-Hill Inc.

Zakaria, E., Chin, L.C. \& Daud, M.Y. (2010). The effects of cooperative learning on students' mathematics achievement and attitude towards mathematics. Journal of Social Science, 6: 272275. 


\section{AUTHORS' BIOGRAPHY}

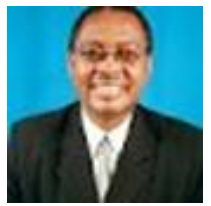

Samuel W. Wachanga, is a full professor of Chemistry Education in Egerton University's Faculty of Education \& Community Studies. Recently, he was appointed acting Deputy Vice-Chancellor (Administration, Planning \& Development). Previously he served as Dean of the Faculty of Education and Community Studies. He has extensive experience in science curriculum development and supervision of student teachers in practicum. His research interest is in the use of Cooperative Learning in teaching. How cooperative learning affects learners acquisition of affective, cognitive and psychomotor outcomes of teaching.

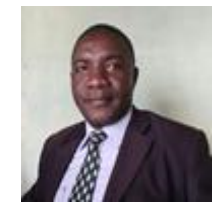

Henry Nyabiosi, is a high school teacher of languages, particularly, Kiswahili. He has just completed his studies leading to a Masters degree. His interests are in literacy empowerment beyond the millenium development goals. In addition, he is interested in development of learners self-concept through teaching of Kiswahili.

Aswan Buliba, is an Associate Professor of Kiswahilli with a long experience in university teaching. Currently he is teaching at Laikipia University in Kenya where he is also serving as the Director of Postgraduate Studies. He is widely published in the area of teaching and learning of languages. 